\title{
RAPID HIV DIAGNOSTIC TEST IN UNDOCUMENTED PREGNANT WOMEN APPLIED AT AN INNER-CITY TEACHING HOSPITAL
}

Luiz Euribel PRESTES-CARNEIRO(1), Nadia Araújo MIGUEL(1), Eloah Lopes ASCÊNCIO(1), Marisa AMÂNCIO(1), Vera Lúcia Maria ALCÂNTARA(2) \& José Alexandre PORTELINHA-FILHO(3)

\begin{abstract}
SUMMARY
A significant number of Brazilian gestational-age women are still not tested for HIV, representing a high risk of transmission to their newborns. The current study sought to identify the number of pregnant women with no previous testing or undocumented for HIV referred to the Gynecology and Obstetrics Department of a Regional Teaching Hospital and included diagnosis of HIV infection determined by a rapid test and perinatal transmission in pregnancy. Medical records of all pregnant women admitted to hospital from January 2001 to December 2005 were reviewed. Pregnant women without HIV results were submitted to a rapid HIV test. Those who tested positive were further tested by ELISA and confirmed by indirect immunofluorescence assay (IIA) or Western blot (WB). The viral load from babies born to HIV-infected mothers was assessed by bDNA. Of the 16,424 pregnant women analyzed (6.6\%), 1,089 were undocumented for HIV. Eleven women were positive in rapid testing and 10 were confirmed by ELISA, IIA or WB, with $0.9 \%$ seropositivity. Mother/infant pairs received zidovudine monotherapy prophylaxis and infant viral load was lower than $50 \mathrm{copies} / \mathrm{mL}$. A higher number of pregnant women previously tested for HIV during antenatal care was verified, compared to that obtained nationwide.
\end{abstract}

KEYWORDS: HIV; Rapid test; Vertical transmission.

\section{INTRODUCTION}

The AIDS epidemic affects approximately 33 million people worldwide. In Latin America, the infection remains generally stable and almost half of the people living with HIV are women. In the last decade there has been an increase in the incidence of HIV/AIDS among young women and a large proportion of infections can be attributed to the behavior of their male sexual partners ${ }^{1,16,32}$. This factor is even more evident where the heterosexual relationship is the dominant manner of HIV transmission ${ }^{25,32}$. Married women form the epidemiological group with the greatest increase in HIV-infection, due to the large number of women who are not aware of their husbands' HIV status ${ }^{32}$. In the state of São Paulo, the female/male ratio of new HIV infections shifted progressively from 1:27 in the 1980's to $1: 3$ by the mid 1990's, to $1: 2$ of new cases during the last five years. In some Brazilian regions, the infection ratio between the sexes is already $1: 1^{30}$.

Since most of the infected women are of reproductive age, another branch of the expanding HIV epidemic is perinatal virus transmission. Approximately $5-10 \%$ of all cases of HIV are children. The majority acquire the infection through mother-to-child transmission (MTCT) inside the uterus, during labor or delivery, or by breastfeeding. Most of these cases live in sub-Saharan Africa ${ }^{16,32}$ and the global epidemiology of pediatric HIV infection reflects the epidemiology of HIV among women ${ }^{32}$.
Worldwide, a significant number of pregnant women are not tested for HIV before labor and delivery, thus they represent a high-risk population ${ }^{10}$. In Brazil, efforts have been made to expand antenatal counseling, to offer HIV testing to all pregnant women and to improve subsequent management of HIV-positive patients ${ }^{4,5,14,22}$. Several authors have discussed the advantages and cost-effectiveness of rapid HIV testing and prophylaxis with zidovudine in preventing MTCT $^{23}$. In the United States, it was demonstrated that this procedure would prevent vertical transmission and save US\$3,000,000/year compared with no intervention $^{21}$. In Mexico, a similar protocol was effective at reducing MTCT, increasing the coverage of pregnant women tested from $4 \%$ to $85 \%$, while saving US\$ 42,517 per child infection ${ }^{29}$.

A growing number of developed ${ }^{5}$ and developing countries have included rapid HIV screening in Public Health Programs. The protocol was included not only in maternity services, but also in places where antenatal care and laboratories facilities were not available ${ }^{26,27}$. Despite public health actions, some HIV-infected women are not aware of their HIV seropositive status prior to delivery. Therefore, they present a high risk of transmitting the virus to their newborns. The study objective was to use a rapid HIV test as a strategy to determine HIV prevalence and to prevent MTCT in pregnant women who had not been previously tested or were undocumented for HIV and were referred to the Gynecology and Obstetrics Service of a Regional Teaching Hospital.

(1) Departamento de Imunologia e Pós-Graduação e Pesquisa, Universidade do Oeste Paulista (Unoeste), Presidente Prudente, SP, Brasil.

(2) Instituto Adolfo Lutz, Presidente Prudente, SP, Brasil.

(3) Departamento de Moléstias Infecciosas, Hospital Universitário "Domingos Leonardo Cerávolo", Presidente Prudente, SP, Brasil.

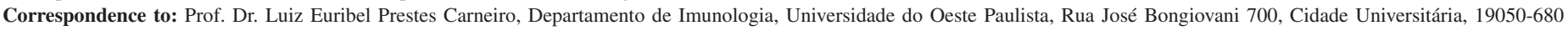
Presidente Prudente, SP, Brasil. Phone/FAX: +55-18-229 1013. Email:luiz@ unoeste.br 


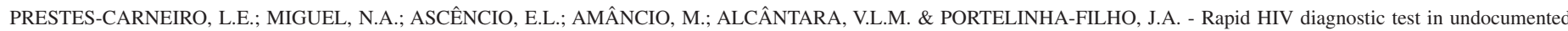
pregnant women applied at an inner-city teaching hospital. Rev. Inst. Med. trop. S. Paulo, 51(5): 273-276, 2009.

\section{MATERIAL AND METHODS}

Patients and Rapid HIV test: The "Dr. Leonardo Domingos Cerávolo" Teaching Hospital (TH) is a Regional General Hospital that serves a population of about 600,000 and is located in the city of Presidente Prudente, in one of the poorest regions of the State of São Paulo, Brazil. The study was conducted from January 2001 to December 2005 on 16,424 pregnant referred to the Gynecology and Obstetrics Service of the TH. This was a retrospective study and was approved by the Institutional Ethics Committee (CEP), under protocol No 106/2004. The anonymity of the patients was maintained.

Pregnant women, in the intrapartum period, and those submitted to obstetric-gynecological procedures, mainly abortion, but also including moderate and severe preeclampsia, urinary tract infection, gestational diabetes and anemia treatment, were all screened. Of the 16,424 individuals referred to the service, a rapid HIV test was used on $1,089(6.6 \%)$. The inclusion criteria were that they had not been tested during antenatal care or were undocumented for HIV (required in the admission box).

Determination of HIV-1/2 (Abbott Laboratories, Tokyo, Japan) was performed by an immunochromatographic rapid test. The reaction was based on the sandwich immunoassay technique with HIV-1 and HIV-2 recombinant antigens, as well as peptides of HIV-1 and HIV-2 envelope antigens. In this study, the strips were analyzed by two trained professionals. In order to implement a rapid HIV test in the TH in 2001, evaluation of Determine HIV-1/2 (Abbott Laboratories, Tokyo, Japan) was conduced in 200 parturients $^{31}$. The test showed specificity and sensitivity of $100 \%$, similar to the rates obtained by different authors with Determine ${ }^{11,13}$.

Enzyme Linked Immunoabsorbent Assay (ELISA): All pregnant women whose serum tested positive by the rapid HIV test were systematically screened for HIV-1/2. Two commercial third-generation assays from different manufacturers were used, according to standard government procedures (ELISA, GENELAVIA ${ }^{\mathrm{R}}$ MIXT, Sanofi Diagnostics Pasteur S.A., Marnes la Coquete, France, and Murex ${ }^{\mathrm{TM}}$ HIV1.2.0, Murex Biotech Limited, Dartford Kent England, UK). When the serum sample that resulted in a positive rapid HIV test was negative by ELISA, it was considered a false positive for HIV screening ${ }^{20}$.

Prophylaxis of HIV-infected mothers detected by rapid HIV test was performed by intravenous injection of $2 \mathrm{mg} / \mathrm{kg}$, followed by continuous infusion of $1 \mathrm{mg} / \mathrm{kg} / \mathrm{h}$ until umbilical cord clamping. The newborns received a six-week course of zidovudine $(2 \mathrm{mg} / \mathrm{kg}$ orally four times per day $)^{4}$. Mothers were counseled not to breastfeed their infants. Clinical or pharmacological support was offered, as recommended by the Governmental Protocol ${ }^{3,4,17}$. After leaving the $\mathrm{TH}$, the mothers were referred to a specialized regional public maternity unit ${ }^{8}$.

Indirect Immunofluorescence Assay (IIA) or Western blot (WB): The confirmatory tests used were indirect immunofluorescence assay (slides from Bio-Manguinhos, Fiocruz Institute, Rio de Janeiro, Brazil) or Western blot (Genelabs Diagnostics Pte. Ltd., Singapore). The reactions were performed according to the manufacturer's recommendations on the serum samples of all women with positive results by ELISA. Whenever the sample was positive by ELISA and IIA or WB, the sample was considered positive for HIV.
bDNA Assay: Quantification of HIV-RNA was performed twice in plasma from newborns of HIV-positive mothers by bDNA. It was assayed using the Chiron Quantiplex version 3bDNA assay (Bayer Corporation, Emervylle, California, USA), according to the manufacturer's instructions. The quantitative detection limits ranged from 50 to 500,000 copies $/ \mathrm{mL}$. The assays were determined at the end of the second month and immediately after the fourth month. This protocol is in accordance with the Brazilian STD/AIDS program ${ }^{4,17}$.

Statistical analysis: Data are expressed as mean \pm SEM and statistical analysis consisted of the Student t test. Statistical significance was set at alpha lower than $5 \%$.

\section{RESULTS}

Of the 16,424 women analyzed, 1,089 (6.6\%) had not been previously tested or were undocumented for HIV status. Most of them, 15,335 (94.4\%) were tested in public health care centers or private clinics. About $70 \%$ of women were attended within the Unified National Health System (SUS) and 30\% used the private sector. Less than $0.1 \%$ of the pregnant women who were attended by the private sector did not have antenatal care and HIV test.

Rapid HIV test: Of the 1,089 non-HIV-tested or undocumented women, $11(1.0 \%)$ tested positive and 1,078 (99.0\%) tested negative for HIV. All the women that tested positive for the rapid HIV test were attended by the SUS. In the present study, all the eligible patients agreed to be tested.

Confirmatory Tests: Among the 11 specimens with a positive result by rapid HIV testing, $10(0.91 \%)$ were confirmed by two distinct ELISA tests. One serum sample was negative (classified as a false positive), with a positivity of $0.9 \%$ for HIV infection. The 10 specimens that tested positive by ELISA were confirmed by IIA or WB. Among the HIV-positive women, six $(60 \%)$ had not been tested during antenatal care. Four (40\%) reported that they had previously been tested but were undocumented for HIV and two were being treated with antiretroviral therapy. Six $(60 \%)$ were admitted during the intra-partum period, two (20\%) underwent vaginal delivery, one (10\%) had an emergency cesarean and three $(30 \%)$ had elective cesarean sections. Four women $(40 \%)$ were admitted for other gynecological procedures. In relation to ethnicity, eight (80\%) were of European descent and two (20\%) were of African or African-European descent. One woman (10\%) was $\leq 18$ years-old, five (50\%) 18-30 years-old and four (40\%) were older than 31 years-old. The time of membrane rupture (hours) for the mothers was not different from the normal range at the $\mathrm{TH}$.

bDNA Assay: All the live-born infants from HIV-infected mothers showed a viral load lower than 50 copies $/ \mathrm{mL}$, according to tests performed at least twice after birth.

\section{DISCUSSION}

Globally, a considerable number of women remain unaware of their HIV serological status during the labor period ${ }^{2,6,28}$. Brazil was one of the first developing countries to implement measures to prevent MTCT of HIV. These efforts promoted a decrease in vertical transmission rates from $20 \%-30 \%$ detected in studies prior to ARV prophylaxis to $2 \%-5 \%$ 
PRESTES-CARNEIRO, L.E.; MIGUEL, N.A.; ASCÊNCIO, E.L.; AMÂNCIO, M.; ALCÂNTARA, V.L.M. \& PORTELINHA-FILHO, J.A. - Rapid HIV diagnostic test in undocumented pregnant women applied at an inner-city teaching hospital. Rev. Inst. Med. trop. S. Paulo, 51(5): 273-276, 2009.

in the last few years ${ }^{15,17,19}$. A nationwide program of rapid HIV testing was one of the main strategies introduced during labor or at delivery by the Brazilian STD/AIDS program, to reduce the risk of perinatal transmission ${ }^{3,4}$.

A higher number $(93.4 \%)$ of pregnant women previously tested for HIV during antenatal care was verified compared to that obtained nationwide $(85 \%)^{20}$. One possible explanation is the higher number of Public Health Care Centers distributed throughout the counties of the region. In these units, following the National Program of Obstetrics and Neonatal Attention, doctors are oriented to screen pregnant women for HIV. Furthermore, pregnant women at high-risk of infection by HIV and not previously tested during antenatal care are preferentially directed to a specialized regional public maternity unit ${ }^{8}$.

In our region, the service within the Teaching Hospital is important for providing services to the SUS. Significant differences are described nationwide between patients attended at private and public maternities. Similar to the results obtained here, several authors have reported that pregnant women who come from less privileged social conditions, such as low income and poor access to prenatal care, are usually not counseled and tested for HIV ${ }^{7,14,17,24}$. In these situations, rapid HIV testing is of special interest.

On the other hand, in the city of Ribeirão Preto, $20.1 \%$ of the pregnant women attended by the Gynecology and Obstetrics Service of the Hospital das Clínicas, from February to June 2001 were not screened at antenatal care clinics ${ }^{11}$. MATIDA et al. $(2005)^{19}$ verified that in the State of São Paulo, about $15 \%$ of parturients were tested by rapid HIV test during maternity. In the State of Sergipe, screening conduced in three maternities linked to the SUS revealed that only $32.5 \%$ of pregnant women were tested for HIV in antenatal clinics ${ }^{18}$. These results demonstrate the discrepancies and local characteristics of HIV infection around the country.

Despite all the planning and policy making, many factors may be involved in not performing the test as recommended. In this study, several mothers were from small municipalities where the tests are not available; thus, serum samples need to be analyzed in regional laboratories using the ELISA test and the results are only available to the patient several weeks or months after the sampling process.

Among the pregnant women submitted to a rapid HIV infection test, positivity was $0.9 \%$. Several studies have demonstrated the application of rapid HIV tests and the prevalence rates of HIV infection in women during labor periods ${ }^{9,18,22}$. In the State of Sergipe, in the Northeastern region of Brazil, 9,215 rapid HIV tests were performed in women during the intrapartum period who were not previously tested for HIV, resulting in $0.42 \%$ infection $^{18}$. The present data are different from a nationwide survey $(0.42 \%)$ conducted in 2004 using the rapid HIV test, diagnosed during labor and delivery. Similar to this work, the rapid test was applied only in pregnant women with no prior documented HIV results ${ }^{20}$. It is difficult to discuss the reasons why these values were higher than the nationwide data, since risk factors and the probable route of acquisition of the mother's HIV infection were not determined for the patients in this study.

According to the Brazilian STD/AIDS protocol, a child is considered HIV uninfected after at least two negative DNA/PCR or bDNA tests, one of these should be performed after the age of four months-old ${ }^{4,17}$. In this survey, all the children were considered uninfected.

In middle-income regions, such as Brazil and Latin America, it is essential to measure the impact of rapid HIV test screenings as a part of the public effort to prevent MTCT. In the present study, the introduction of a rapid HIV test was efficient to determine the early diagnosis of HIV infection among pregnant women who had not been tested or were undocumented for HIV. Furthermore, this procedure provided an opportunity to administer both antiretroviral prophylaxis and incorporate other obstetric interventions to decrease vertical HIV transmission.

\section{RESUMO}

\section{Diagnóstico da infecção pelo HIV através de um teste rápido em gestantes sem resultados comprobatórios atendidas em um hospital escola do interior}

No Brasil um número significativo de mulheres em idade gestacional ainda não foi testado para HIV, representando risco acentuado de transmissão vertical. Nosso objetivo foi determinar o número de gestantes que não foram previamente testadas ou não portavam documentos comprobatórios para HIV, ou seja, o diagnóstico da infecção para HIV através de um teste rápido e a transmissão vertical em gestantes admitidas no Departamento de Ginecologia e Obstetrícia de um Hospital Universitário Regional. Foram revisados os prontuários das gestantes admitidas entre janeiro de 2001 e dezembro de 2005. Gestantes sem resultados para HIV foram submetidas a um teste rápido. Testes positivos foram submetidos ao teste de ELISA e confirmados por imunofluorescência indireta (IIA) ou Western blot (WB). A carga viral dos recém-nascidos de mães infectadas foi determinada por bDNA. Dentre as 16.424 gestantes analisadas, 6,6\% (1.089) não apresentaram resultados comprobatórios. Onze gestantes tiveram resultados positivos no teste rápido e 10 foram confirmadas por ELISA, IIA ou WB com $0,9 \%$ de positividade. Mães e recém-nascidos receberam profilaxia com zidovudina e todos os recém-nascidos tiveram carga viral inferior a 50 copias $/ \mathrm{mL}$. Foi encontrado um número maior de gestantes previamente testadas para HIV quando comparado à média obtida no país.

\section{REFERENCES}

1. BASSICHETTO, K.C.; BERGAMASCHI, D.P.; OLIVEIRA, S.M. et al. - Elevated risk for HIV-1 infection in adolescents and young adults in São Paulo, Brazil. PLoSONE., 3: e1423, 2008.

2. BITNUN, A.; KING, S.M.; ARNESON, C. \& READ, S.E. - Failure to prevent HIV infection. Canad. med. Ass. J., 167: 904-905, 2002.

3. BRASIL. MINISTÉRIO DA SAÚDE. DEPARTAMENTO DE VIGILÂNCIA EPIDEMIOLÓGICA. PROGRAMA NACIONAL DE DST/AIDS - Teste rápido para HIV: considerações gerais sobre o seu uso com ênfase na indicação de terapia antiretroviral em situações de emergência. Brasília, Ministério da Saúde, 2001.

4. BRASIL. MINISTÉRIO DA SAÚDE. SECRETARIA DE VIGILÃNCIA EM SAÚDE PROGRAMA NACIONAL DE DST e AIDS - Recomendações para profilaxia da transmissão vertical do HIV e terapia anti-retroviral em gestantes. Brasília, 2006. (Manual No. 46).

5. BULTERYS, M.; JAMIESON, D.J.; O'SULLIVAN, M.J. et al. - Rapid HIV-1 testing during labor: a multicenter study. J. Amer. med. Ass., 292: 219-223, 2004. 
PRESTES-CARNEIRO, L.E.; MIGUEL, N.A.; ASCÊNCIO, E.L.; AMÂNCIO, M.; ALCÂNTARA, V.L.M. \& PORTELINHA-FILHO, J.A. - Rapid HIV diagnostic test in undocumented pregnant women applied at an inner-city teaching hospital. Rev. Inst. Med. trop. S. Paulo, 51(5): 273-276, 2009.

6. CHALERMCHOCKCHAROENKIT, A.; LOUISIRIROTCHNAKUL, S.; ROONGPISUTHIPONG. A.; SIRIMAI, K.; SUTCHRITPONGSA, P. \& WASI, C. - Rapid human immunodeficiency virus diagnostic test during the intrapartum period in pregnant women who did not receive antenatal care. J. med. Ass. Thai., 85: 703-708, 2002.

7. CHRYSTIE, I.L.; WOLFE, C.D.; KENNEDY. J. et al. - Voluntary, named testing for HIV in a community based antenatal clinic: a pilot study. Brit. med. J., 311: 928-931, 1995.

8. CREMONEZI, D.; MESQUITA, P.E.; ROMAO, M.M. \& PRESTES-CARNEIRO, L.E. - Prevalence of indeterminate human immunodeficiency virus Western blot results in pregnant women attended at a public hospital in Presidente Prudente, Brazil. Braz. J. infect. Dis., 9: 506-509, 2005.

9. DEL BIANCO, R.; DANTAS, S.; SEABRA, J.N. et al. - Prevention of mother-to-child transmission of HIV in five maternity in Sao Paulo City, Brazil. In: INTERNATIONAL AIDS CONFERENCE, 15, Bangkok, 2004. Abstract. B10748.

10. D'IPPOLITO, M.; READ, J.S.; KORELITZ, J. et al. - Missed opportunities for prevention of mother-to-child transmission of human immunodeficiency virus type 1 in Latin America and the Caribbean: the NISDI perinatal study. Pediat. infect. Dis. J., 26: 649-653, 2007 .

11. DUARTE, G.; GONÇALVES, C.V.; MARCOLIN, A.C. et al. - Teste rápido para detecção da infecção pelo HIV-1 em gestantes. Rev. bras. Ginec. Obstet., 23: 107$111,2001$.

12. El BEITUNE, P.; DUARTE, G.; QUINTANA, S.M. \& FIGUEIRO-FILHO, E.A. HIV-1: maternal prognosis. Rev. Hosp. Clin. Fac. Med. S. Paulo, 59: 25-31, 2004.

13. FERREIRA JUNIOR, O.C.; FERREIRA, C.; RIEDEL, M.; WIDOLIN, M.R. \& BARBOSA Jr., A. - Evaluation of rapid tests for anti-HIV detection in Brazil. AIDS, 19 (suppl. 4): 70-75, 2005.

14. GOLDANI, M.Z.; GIUGLIANI, E.R.; SCANLON, T. et al. - Voluntary HIV counseling and testing during prenatal care in Brazil. Rev. Saúde públ. (S. Paulo), 37: 552-558, 2003

15. KAKEHASI, F.M.; PINTO, J.A.; ROMANELLI, R.M. et al. - Determinants and trends in perinatal human immunodeficiency virus type 1 (HIV-1) transmission in the metropolitan area of Belo Horizonte, Brazil: 1998 - 2005. Mem. Inst. Oswaldo Cruz, 103: 351-357, 2008.

16. KALLINGS, L.O. - The first postmodern pandemic: 25 years of HIV/ AIDS. J. intern. Med., 263: 218-243, 2008.

17. KREITCHMANN, R.; FUCHS, S.C.; SUFFERT, T. \& PREUSSLER, G. - Perinatal HIV-1 transmission among low income women participants in the HIV/AIDS Control Program in Southern Brazil: a cohort study. Brit. J. Obstet. Gynaec., 111: 579-584, 2004.

18. LEMOS, L.M.D.; GURGEL, R.Q. \& FABBRO, A.L.D. - HIV virus prevalence in unified care system maternity. Available at http://www.portaldeginecologia.com.br (accessed Dec 21, 2006).

19. MATIDA, L.H.; DA SILVA, M.H.; TAYRA, A. et al. - Prevention of mother-to-child transmission of HIV in São Paulo State, Brazil: an update. AIDS, 19 (suppl. 4): 37-41, 2005.
20. MINISTÉRIO DA SAÚDE. Programa Nacional de DST e AIDS. Available at: http:/ www.aids.gov.br (accessed July 12, 2008).

21. MRUS, J.M. \& TSEVAT, J. - Cost-effectiveness of interventions to reduce vertical HIV transmission from pregnant women who have not received prenatal care. Med. Decis. Making, 24: 30-39, 2004.

22. NEVES, F.R.A.L.; PASSOS, A.D.C. \& GUELERI, W.L. - Disponibilidade de sorologia anti-HIV como um teste voluntário na rotina do atendimento pré-natal em unidades básicas de saúde. Rev. Saúde públ. (S. Paulo), 33: 624-625, 1999.

23. NIGHTINGALE, S. \& DABIS, F. - Evidence behind the WHO guidelines: hospital care for children: what antiretroviral agents and regimens are effective in the prevention of mother-to-child transmission of HIV? J. trop. Pediat., 52: 235-238, 2006

24. NISHIMOTO, T.M.; ELUF, N.J. \& ROZMAN, M.A. - Transmissão materno-infanti do vírus da imunodeficiência humana: avaliação de medidas de contrôle no município de Santos. Rev. Ass. méd. bras., 51: 54-60, 2005.

25. NOGUEIRA, S.A.; ABREU, T.; OLIVEIRA, R. et al. - Successful prevention of HIV transmission from mother to infant in Brazil using a multidisciplinary team approach. Braz. J. infect. Dis., 5: 78-86, 2001

26. PEREZ, F.; MUKOTEKWA, T.; MILLER, A. et al. - Implementing a rural programme of prevention of mother-to-child transmission of HIV in Zimbabwe: first 18 months of experience. Trop. Med. Int. HIth, 9: 774-783, 2004.

27. RAJEGOWDA, B.K.; DAS, B.B.; LALA, R.; RAO, S. \& Mc NEELEY, D.F. Expedited human immunodeficiency virus testing of mothers and newborns with unknown HIV status at time of labor and delivery. J. Perinat. Med., 28: 458-463, 2000

28. REDELINGS, M.D.; FRYE, D.M. \& SORVILLO, F. - High incidence of HIVassociated mortality among black and Hispanic infants and women of childbearing age in the United States 1990-2001. J. Acquir. Immune Defic. Syndr., 39: 496-498, 2005.

29. RELY, K.; BERTOZZI, S.M.; AVILA-FIGUEROA, C. \& GUIJARRO, M.T. - Costeffectiveness of strategies to reduce mother-to-child HIV transmission in Mexico, a low-prevalence setting. Hlth Policy Plan., 18: 290-298, 2003.

30. STRAZZA, L.; AZEVEDO, R.S.; CARVALHO, H.B. \& MASSAD, E. - The vulnerability of Brazilian female prisoners to HIV infection. Braz. J. med. biol. Res., 37: 771-776, 2004.

31. TRINDADE, T.C.; CARMO, A.C.S.; ALMEIDA, M.C. \& PRESTES-CARNEIRO, L.E. - Comparação do teste rápido na detecção da infecção pelo HIV $1 / 2 \mathrm{em}$ parturientes. Newslab, 48: 108-118, 2001.

32. UNAIDS - AIDS epidemic update 2007. Available at http://www.unaids.org (accessed May 12, 2008).

33. WATTS, D.H. - Treating HIV during pregnancy: an update on safety issues. Drug Saf., 29: 467-490, 2006.

Received: 12 June 2008

Accepted: 7 July 2009 